\title{
ERITYISIÄ MATKUSTAJIA: LIIKKUMISEN VALMIUDET SAIRASVAKUUTUKSEN MATKAKORVAUSJÄRJESTELMÄN KAUTTA TARKASTELTUNA
}

Elina Turunen: VTM, väitöskirjatutkija, Helsingin yliopisto

Anna-Maria Isola: VTT, tutkimuspäällikeö, Terveyden ja byvinvoinnin laitos

Heikki Hiilamo: VTT, FT, professori, Helsingin yliopisto, tutkimusprofessori, Terveyden ja byvinvoinnin laitos

elina.turunen@belsinki.fi; anna-maria.isola@thl.fi; heikki.hiilamo@tbl.fi

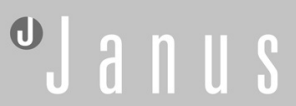

Janus vol. 29 (4) 2021, 315-331

Tiivistelmä

Terveydenhuoltoon ja kuntoutukseen suuntautuvien matkojen kustannuksia korvataan sairausvakuutuksesta. Kela siirtyi sairausvakuutuksen korvaamissa taksimatkoissa vuosina 2010-2014 sairaanhoitopiirikohtaisen tilausvälityskeskuksen käyttöön tavoitteena säästää kustannuksissa matkoja yhdistelemällä. Oikeus palvelun käyttöön ei välttämättä merkitse oikeuden toteutumista. Resurssit täytyy pystyä muuntamaan toiminnoiksi. Kysymme, miten matkustajat kokevat matkakorvausjärjestelmän lisäävän tai rajoittavan liikkumiseen liittyviä toimintavalmiuksia. Tutkimuksessa haastateltiin vuodenvaihteessa 2014-2015 yhteensä 16 henkilöä. Toimintavalmiuksiin vaikuttivat matkustajaan ja läheiseen, ympäristöön, palvelujen järjestämiseen ja kuljettajan toimintaan liittyvät konversiotekijät, kuten henkilökohtaisia tarpeita vastaava apu. Sosiaaliset seikat kuten matkustajan tunteminen, aloitteellisuus, kommunikaatio ja luottamus koettiin tärkeiksi.

\section{JOHDANTO}

Terveyspalvelujen saavutettavuuteen vaikuttavat monet eri tekijät, kuten palvelujen laatu, määrä, hinta ja sijainti. Suomessa on pitkät etäisyydet, mutta pieni väestö, 5,5 miljoonaa asukasta 311 kunnassa. Asukkaista noin kolmannes on keskittynyt kuuteen suurimpaan kaupunkiin (Tilastokeskus 2018). Harvaan asutuilla alueilla etäisyydet palvelujen äärelle ovat usein pitkiä. Myös lähellä sijaitseva palvelu voi olla vaikeasti saavutettavissa, jos liikkumisen valmiudet ovat heikentyneet. Suomessa julkiseen terveyspalvelujärjestelmään kuuluu matkakustannusten korvaaminen (L 1224/2004). Sairausvakuutuksesta maksetaan korvauksia matkakustannuksista julkiseen tai yksityiseen sairaanhoitoon, raskauteen ja synnytykseen liittyvien matkojen kustannuksista ja samoin korvataan Kelan kuntoutukseen liittyvien matkojen kustannuksia. Perinteinen palvelutarpeiden arvioinnin mekaaninen malli ei välttämättä tavoita matkustajien tilanteiden moninaisuutta ja siksi tarvitaan toimintavalmiuksille pohjautuvaa palvelua. Tämä artikkeli tarkastelee matkakorvausten käyttäjien taksimatkoihin liittyviä toimintavalmiuksia asiakashaastatteluiden avulla.

Toimintavalmiudet (Sen 1993) kuvaavat ihmisen mahdollisuuksia saavuttaa erilaisia toimintoja henkilökohtaisten ja yhteiskunnallisten tekijöiden sekä ympäristön olosuhteiden rajoissa. Ihmisten lähtökohdat ja tilanteet ovat erilaisia ja 
avuntarve vaihtelee. Esimerkiksi yksilö ei välttämättä saa tarvitsemaansa hoitoa joidenkin rakenteellisten tekijöiden, kuten monimutkaisen hoitoon pääsyn, vuoksi. Tarkastelemalla liikkumista toimintavalmiuksien kautta voimme analysoida, mitkä tekijät auttavat ja estävät liikkumista. Pelkkä saatavilla oleva resurssi ei Amartya Senin (2009) mukaan välttämättä merkitse, että sitä voisi hyödyntää. Esimerkiksi oikeus palveluun ei välttämättä johda oikeuden toteutumiseen. Toimintavalmiuksien tutkiminen auttaa tarkastelemaan hyvinvoinnin rakentumista kokonaisuutena.

Seuraavassa matkakorvausjärjestelmää tarkastellaan toimintavalmiuksien viitekehyksessä matkojen toteutumisen osalta. Näin saadaan tietoa siitä, mitkä tekijät vaikuttavat matkojen toteutumiseen. Tutkimuksessa kysytään, miten matkustajat kokevat sairausvakuutuksen matkakorvausjärjestelmän lisäävän tai rajoittavan liikkumiseen liittyviä toimintavalmiuksia.

\section{MatkakorvausjärJestelmä JA AIKAISEMPI TUTKIMUS}

Matkakorvausjärjestelmä korvaa kustannuksia matkakohtaisen omavastuun (25 euroa/yhdensuuntainen matka vuonna 2019) ylittävältä osalta.Vuotuisen omavastuukaton (300 euroa vuonna 2019) ylittävät kustannukset korvataan kokonaan. Taksimatkojen kustannuksia korvataan, kun julkista liikennettä ei ole tai se on puutteellista. Taksimatkoja korvataan myös, jos niiden käyttöön on terveydellinen syy. (Kela 2019a.) Suorakorvausjärjestelmässä matkustaja maksaa omavastuuosuuden. Joukkoliikenteellä tai omalla autolla kuljettaessa matkustaja sen sijaan maksaa matkan ensin itse ja voi hakea korvauksia jälkikäteen. (Kela 2018a.)

Korvausjärjestelmän säännöt rajaavat mahdollisuuksia vaikuttaa matkantekoon. Matkustajan terveydentilan vuoksi on joskus käytettävä niin sanottua erityisajoneuvoa, kuten omaa autoa tai taksia (Kela 2018b). Matkustajalla voi olla oikeus esimerkiksi käyttää entuudestaan tuttua taksia. Asia punnitaan tapauskohtaisesti ja terveydentila huomioon ottaen. ${ }^{1}$ Alle 16 -vuotiaat yksin matkustavat lapset ja vaikeasti sairaat lapset saavat myös käyttää tuttua kuljettajaa. (Kela 2018c.) Matkustaja valitsee haluamansa autoilijan, joka tietää millaista apua matkustaja tarvitsee.

Kela siirtyi vuosina 2010-2014 sairaanhoitopiirikohtaiseen tilausvälityskeskuksen käyttöön sairausvakuutuksen korvaamissa taksimatkoissa. Matkat alettiin välittää keskuksen kautta järjestelmään liittyneille autoilijoille. Tavoitteena oli säästää kustannuksia yhdistelemällä samaan suuntaan liikkuvien ihmisten matkoja. Kyytejä oli mahdollista tilata tilausvälityskeskuksesta kerralla vähintään kahden viikon ajalle (Kela 2018d,7-11). Taksin saapumisaika oli ilmoitettava asiakkaalle 10 minuutin tarkkuudella matkaa tilatessa. Saapumisaika voitiin ilmoittaa myös myöhemmin, mikäli matka esimerkiksi yhdisteltiin. (Kela 2013, 16.) Tilausvälityskeskus saattoi odottaa toista samaan suuntaan menevää tilausta, joka voitiin yhdistää ensimmäiseen. Matkustaja joutui odottamaan kuljetusta kotiin enintään tunnin (Kela 2018e). Tuttua taksia käyttävät matkustajat saattoivat käytännössä sopia matkasta kuljettajan kanssa. 
Matkakorvauksista aiheutuvat kustannukset ovat lisääntyneet viime vuosina ja niitä on pyritty rajoittamaan matkoja yhdistelemällä ja omavastuuosuutta korottamalla (Kela 2019b). Vuoden 2015 alusta muualta kuin tilausvälityskeskuksesta tilatun matkan omavastuu oli kaksinkertainen. Sitä ei myöskään laskettu vuotuiseen omavastuuosuuteen. (L 1256/2014.) Tämä vaikutti mahdollisuuteen tilata kyyti tutulta kuljettajalta, toisin sanoen muualta kuin keskuksesta.

Sairausvakuutuksen korvaamien matkojen lisäksi kunnat korvaavat matkoja vammaispalvelulain (L380/1987) ja sosiaalihuoltolain (L1301/2014) perusteella. Sairausvakuutuksen matkakorvauksia on tarkasteltu etenkin rekisteriaineistojen avulla. Rekisteriaineistojen pohjalta tehdyn tutkimuksen (Tillman \& Miettinen 2016) perusteella tiedetään esimerkiksi, että yhteiskunnan tukemia kuljetuksia saadaan usein samanaikaisesti: noin puolet vammaispalvelu- ja sosiaalihuoltolain mukaisiin kuljetuksiin oikeutetuista sai myös sairausvakuutuslain mukaisia matkakorvauksia kiireettömistä matkoista Oulussa vuonna 2013. Kuntien edustajat ovat toivoneet niin sanottujen Kela- ja vammaispalvelulain mukaisten matkojen yhdistelyä sekä kimppakyytejä, etenkin haja-asutusalueella ja maaseudulla (Sirola ja Nurmi-Koikkalainen 2014). Kuntien kuljetuspalvelumatkoja koskevissa tutkimuksissa yhdistely sopi osalle (Puumalainen ym. 2014) tai suurimmalle osalle (Kiljunen 2012) matkustajista.

Kuljetuspalvelumatkoja koskevissa tutkimuksissa on tullut esille, että matkustajat ovat olleet tyytymättömiä kyydin odottamiseen ja myöhästymi- seen. Matkoja on jäänyt käyttämättä muun muassa niiden epäluotettavuuden vuoksi. (Mölkänen 2008; Kiljunen 2012; Puumalainen ym. 2014; Sirola \& Nurmi-Koikkalainen 2014; Asikainen 2015; Salminen 2015; Huttunen 2019.) Ruotsissa Svensk Kollektivtrafikin (2017) barometrissä vammaisille suunnattujen ja sairauteen liittyvien matkojen keskeisimmiksi kehityskohteiksi säännöllisesti matkustavilla nousivat odotusaika puhelimessa, tilaamiseen liittyvä palvelu ja kuljetuksen toivottu ajankohta. Matkan myöhästyminen vähensi tyytyväisyyttä puhelimessa jonottamista enemmän kaikilla matkustajilla. Harvoin tai ei koskaan matkustavat olivat päivittäin matkustavia tyytyväisempiä matkojen toimintaan yleensä vuonna 2016.

Aikaisemmissa tutkimuksissa on tarkasteltu myös kuljettajien roolia. Tutut kuljettajat olivat auttaneet enemmänkin kuin heidän tehtäväänsä olisi kuulunut (Sipponen 2006; Tedre \& Pulkkinen 2011; Huttunen 2019). Apu oli ollut esimerkiksi henkistä tukea ja wc:ssä käynnin avustamista. Asiakkaille matkalla saattoi olla sosiaalista merkitystä, sillä kuljettajista oli matkustajille myös seuraa (Sipponen 2006). Kuljettajan apu oli sikäli merkittävää, että osa ei tämän vuoksi tarvinnut avustajaa (Puumalainen ym. 2014). Taksinkuljettajille tehdyssä kyselyssä (Paltta 2010) tuli myös esille, että taksinkuljettajat antoivat asiakkailleen apua esimerkiksi liikkumiseen. Matkustajat olivat kokeneet kuljetuspalvelumatkoilla puutteita turvallisuudessa esimerkiksi silloin, kun vieras kuljettaja avusti heitä ja kun matkoja yhdisteltiin muiden ihmisten matkojen kanssa (Sipponen 2006; Asikainen 2015; Sirola \& Nurmi- 
Koikkalainen 2014), mutta yhdessä selvityksessä (Kiljunen 2012) suurin osa asiakkaista ja henkilökunnasta piti matkoja turvallisina. Kuljetuksissa ei koettu merkittäviä ongelmia, kun matkustajien tiedot olivat ajantasaisia (Salminen 2015).

Kulkemista ja ikääntyvien maalla asumisen mahdollisuuksia tarkastelleiden Silva Tedren ja Anneli Pulkkisen (2011) mukaan kulkeminen vaikuttaa mahdollisuuksiin osallistua, esimerkiksi auton omistaminen voi vaikuttaa palvelujen käyttöön. Toisaalta kulkeminen on muutakin kuin paikasta toiseen siirtymistä, se on esimerkiksi sosiaalista. Välimatkat myös ohjaavat arjen käytäntöjä (Lehtola \& Tedre 2014), esimerkiksi kuinka usein kuljetaan hoitamaan asioita.

Aiemman tutkimuksen perusteella voidaan olettaa, että matkan luotettavuus, kuten ajallaan saapuminen ja aikataulussa pysyminen, on matkustajille tärkeää ja että turvallinen matkanteko tulee esille silloin, kun ihmisillä oli erityistarpeita. Arjen sujuvuus, toiminnan mahdollisuudet ja itsenäinen pärjääminen saattavat olla kiinni matkoista, toisaalta ne myös rakentavat arkea ja sen sosiaalisuutta. Myös kokemuksia sairausvakuutuksen korvaamilta matkoilta on hyödyllistä tutkia laadullisesti. Näin saadaan tietoa siitä, miten terveyspalvelut saavutetaan arjessa käytännössä.

\section{TOIMINTAVAlMiUdeT TEOREETTISENA VIITEKEHYKSENÄ}

Liikkumisen tarkastelu toimintavalmiuksien näkökulmasta kiinnittää huomion liikkumiseen toteutumistaan odottavana mahdollisuutena. Jos toimijuus merkitsee kykyä tehdä jotakin, saada aikaan jokin vaikutus, niin toimintavalmiuksien lähestymistapa korostaa sitä, mitä ja miten henkilö voi valita erilaisten mahdollisuuksien joukosta. Toimintavalmiuksiin vaikuttavat saatavilla olevat resurssit ja yksilöllisesti vaihtelevat tarpeet. Toimintavalmiuksien viitekehys keskittyy joidenkin tutkijoiden mukaan yksilöön eikä huomaa kollektiivisia toimijoita (Douglas ja Ney 1998; Navarro 2000). Lähestymistapaa on kehitetty edelleen relationaalisesta (Smith \& Seward 2009) ja kollektiivisen päätöksenteon (Deneulin \& McGregor 2010) näkökulmasta. Toimintavalmiuksien lähestymistapa huomioi sosiaalisen ympäristön vaikutuksen mahdollisuuksiin muuntaa resurssit toimintavalmiuksiksi ja toteutuneiksi toiminnoiksi. Tässä tutkimuksessa ymmärrämme, että yksilöiden voimavarat ovat monin tavoin rajallisia ja toiminnan mahdollistaminen edellyttää usein sosiaalista vuorovaikutusta. Institutionaaliset esteet voivat myös vaikeuttaa tai estää toimintaa.

Senin (1993) kehikossa korostuu ihmisten vapaus elää omien arvojensa mukaisesti. Toiminta ei ole vain välineellistä, vaan se voi olla myös itsessään tärkeää. Ajattelemme, että liikkuminen on tavoite itsessään. Hyvinvoinnin saavuttaminen voi tarkoittaa esimerkiksi jonkin hyvinvointia lisäävän palvelun saamista. Hyvinvoinnin vapaus on muun muassa vapautta valita hyvinvointia edistävien asioiden välillä. Mahdollisuus liikkua voi vaikuttaa myös toimijuuteen, jossa on kyse siitä, miten henkilö menestyy erilaisten tavoitteidensa tavoittelussa. Toimijuuden vapaus taas merkitsee va- 
pautta valita mitä tekee ja miten toimii. (Sen 1985; 1993.)

Toimintavalmiudet ovat erilaisia sosiaalisissa suhteissa rakentuvia olemisten ja tekemisten mahdollisia yhdistelmiä, joista voi valita minkä tahansa (Sen 1993). Resurssit täytyy pystyä muuttamaan käytännössä toimintavalmiuksiksi (capabilities). Mahdollisuuksiin hyödyntää resursseja vaikuttavat konversiotekijät. Toimintavalmiuksen käyttämistä vapaan valinnan mukaan kutsutaan toiminnoiksi (functionings). (Sen 2000.) Tämän tutkimuksen kohteena ovat resurssit, konversiotekijät ja toimintamahdollisuudet. Jaamme konversiotekijät tässä henkilökohtaisiin tekijöihin, ympäristön olosuhteisiin ja yhteiskunnallisiin ehtoihin (Sen 2000; 2009). ${ }^{2}$ Resursseista ei välttämättä seuraa toivottuja asioita, jos ihmiseltä puuttuu muutoksen edellyttämiä ominaisuuksia, palveluja tai sosiaalisia suhteita. Esimerkiksi riittävät tulot hyvinvoinnin saavuttamiseksi vaihtelevat, sillä ihmisillä on erilaisia tarpeita ja yhteiskunnat ovat erilaisia (Sen 1993). Konversiotekijät kiinnittävät yksilön suhteisiin ympäristönsä kanssa. Toimintavalmiuksien lähestymistavan avulla voidaan tunnistaa toimijan ja rakenteen dynaamiset suhteet sekä näiden yhteyksien kehittyminen ajan myötä (Hvinden \& Halvorsen 2018).

Purkamalla liikkumisen prosessi osiin päästään analysoimaan niitä tekijöitä, jotka tukevat tai haittaavat liikkumisen resurssien muuttumista itselle tärkeäksi toiminnoksi. Sairaus tai vamma voi aiheuttaa lisäresurssien tarpeen. Jotta toimintavalmiudet säilyisivät kohtuullisina, sosiaalivakuutuksen matkakor- vausjärjestelmä vastaa tähän tarpeeseen Konversiotekijät ratkaisevat, saavuttaako matkustaja liikkumisen tai pääsyn terveydenhuoltoon ja siten paremman terveyden. Koska konversiotekijät ovat riippuvaisia toisistaan, on hyödyllistä tarkastella myös niiden välisiä suhteita. Lois McNayn (2004) mukaan rakenteiden vaikutus tulee esiin eletyissä sosiaalisissa suhteissa. Kuljetukset tapahtuvat ihmisten välisessä vuorovaikutuksessa, jota rakenteet institutionalisoituine käytäntöineen ohjaavat. Sekä vuorovaikutus että käytännöt määrittävät sitä, muuttuuko resurssi tavoitelluksi asiaksi.

Eda Beyazitin (2011) mukaan kuljetustutkimuksen pitäisi ottaa paremmin huomioon ihmisten todelliset tarpeet ja sosiaalinen oikeudenmukaisuus. Susanne Nordbakken fokusryhmätutkimuksen (2013) mukaan vanhemmat ihmiset voivat hallita liikkumistarpeitaan, vaikka heillä ei olisi mahdollisuutta ajaa autoa, jos heillä on kokemusta vaihtoehtoisista liikkumismuodoista, laadukas kuljetusjärjestelmä ja tarjolla on sopivaan aikaan, sopivassa paikassa järjestettyjä aktiviteetteja, joihin pääsystä on huolehdittu. Jean Ryanin (2019) tutkimuksessa esimerkiksi sosiaaliset resurssit ja hyvä terveys, ajokortti ja valmius käyttää julkista liikennettä näkyivät vanhempien ihmisten valmiudessa toteuttaa jokapäiväisiä askareita.

\section{Aineisto JA Menetelmät}

Aineisto kerättiin osana Kelan Sairausvakuutuksen matkakorvaukset -hankekokonaisuutta vuosina 2014-2015. ${ }^{3}$ Tavoitteena oli saada tietoa erilaisista kokemuksista sairausvakuutuksen korvaamien matkojen tekemisestä ja siksi 
keskityttiin tiettyihin korvausten saajaryhmiin. Tässä artikkelissa käytettävä toimintavalmiuksien näkökulma tuotiin mukaan aineiston keräämisen ja ensimmäisen raportin kirjoittamisen jälkeen. Haastateltavien rekrytoinnissa hyödynnettiin potilas- ja vammaisyhdistyksiä, joiden kautta pyrittiin tavoittamaan henkilöitä, joilla on tilastotietoihin perustuen paljon sairauteen tai kuntoutukseen liittyviä matkoja. Haastateltaviksi rekrytoitiin sairaaladialyysipotilaita (Munuais- ja maksaliiton ${ }^{4}$ kautta) ja iäkkäitä henkilöitä (Omaishoitajat ja läheiset -liiton kautta). Haastateltaviksi pyrittiin tavoittamaan myös henkilöitä, jotka mahdollisesti tarvitsivat erityistä apua liikkumisessa ja jotka saivat Kelan vaativaa lääkinnällistä kuntoutusta (näitä haastateltavia etsittiin Aivovammaliiton kautta). Haastateltavaksi pyydettiin täysi-ikäisiä henkilöitä, joilla tai joiden hoivaa tarvitsevilla läheisillä oli paljon sairauteen tai kuntoutukseen liittyviä matkoja ja jotka käyttivät matkakorvauksia.

Tutkimukseen haastateltiin 16 henkilöä joulu-tammikuussa 2014-2015. Yhteen haastatteluun osallistuivat sekä omainen että omaistaan hoitava. Haastateltavat asuivat ympäri Suomen ja olivat iältään 40-89-vuotiaita, valtaosa oli 60-vuotiaita tai sitä vanhempia. Haastateltavista 11 oli naisia ja viisi miehiä. Omaistaan hoitavista seitsemän oli naista ja kaksi miestä. Kaupunkialueella asui kahdeksan, maaseudulla seitsemän, mutta heistä kolme taajamissa. Haastateltavista seitsemän kertoi omista matkoistaan ja yhdeksän hoivan tarvitsijan matkoista. ${ }^{5}$ Haastattelut tehtiin pääosin henkilökohtaisena tapaamisena ja kolme puhelimitse ja yksi sähköpostitse, sillä se oli haastateltavan toiveiden mukaista tai haastattelun järjestäminen oli näin helpompaa. Haastatelluista viisi kävi dialyysihoidossa. Kaksitoista haastateltavista tai hoivan tarvitsijoista käytti tai oli käyttänyt apuvälineitä ja viidellä oli vakiotaksioikeus sairausvakuutuksen korvaamilla matkoilla.

Omaistaan hoitavat ja itse matkustavat eivät olennaisesti eronneet vastauksissaan. Omaistaan hoitavat kertoivat palvelujen käyttäjien kokemuksesta kuten itse matkustavatkin. On kuitenkin muistettava, että omaistaan hoitavat puhuivat omasta näkökulmastaan.

Tutkimukseen osallistuvilta pyydettiin kirjallinen suostumus. Se pyydettiin myös korvausten saajilta itseltään, mutta tätä ei ollut aina mahdollista saada, esimerkiksi vamman, sairauden tai iän vuoksi. Tällöin suostumus saatiin läheiseltä. Aineisto on karkeistettu, jotta henkilöitä ei voisi tunnistaa. Kelan tutkimuseettinen toimikunta puolsi tutkimuksen tekemistä 19.5.2014. Omaistaan hoitavista osa oli tehnyt sairausvakuutuksen korvaamia matkoja itsekin ja he kertoivat joskus myös niistä

Haastattelut nauhoitettiin ja litteroitiin sanatarkasti ${ }^{6}$. Litteroituja sivuja oli 287. Puolesta tunnista reiluun tuntiin kestävät haastattelut tehtiin puolistrukturoituina teemahaastatteluina (Gaskell 2003; Adams 2015). Haastattelujen keskeiset kysymykset koskivat sairaanhoidon matkan toteutumista, matkaan liittyvää apua ja tarpeita, matkakorvausten taloudellista merkitystä, korvauksen hakemista, matkakorvausjärjestelmän kehittämistä ja matkakorvauksen yöpymiskorvausta (Turunen \& Tillman 2017). Tässä artikkelissa keskitytään matkan toteutumiseen arjessa, ja käsit- 
telyn ulkopuolelle jätettiin matkakorvausten hakemiseen ja taloudelliseen merkitykseen, yöpymiskorvaukseen sekä julkiseen liikenteeseen liittyvät teemat. Rajaus pohjautuu siihen, että tässä kiinnostus on etenkin kuljetuksiin liittyvässä avussa, palvelussa ja matkantekoon osallistuvien toiminnassa, toisin sanoen muissa kuin ilmeisimmissä materiaalisissa tekijöissä. Analyysi keskittyy sairausvakuutuksen korvaamiin matkoihin. Joillakin haastatelluilla oli kokemusta myös kuntien kuljetuspalvelumatkoista, jotka eroavat edellisistä ainakin käyttötarkoituksen, määrän ja hinnan puolesta.

Aineisto analysoitiin laadullista sisällönanalyysia käyttäen, hyödyntäen Atlas.tiohjelmaa. Analyysi on teoriaohjaava ja siinä hyödynnettiin toimintavalmiuksien lähestymistapaa. Analyysiyksikkönä oli ajatuskokonaisuus (Tuomi \& Sarajärvi 2009, 95-110), esimerkiksi toive tilata tiedetyt matkat yhdellä kertaa.

Toimintavalmiuksien lähestymistapa ohjasi analyysia siten, että ensin tarkasteltiin tekijöitä, jotka auttavat ja estävät matkojen toteutumista eli vaikuttavat konversiotekijöinä. Havainnoista tehtiin koodeja, joita yhdisteltiin toisiinsa. Esimerkiksi korvausjärjestelmän toimintaan liittyvistä tekijöistä, kuten taksin tilaaminen ja kyytien yhdistely, muodostettiin yksi alakategoria ("Matkakorvausjärjestelmä”). Samoin tehtiin auttavien ja estävien tekijöiden suhteen. Näin syntyivät toiminnan osapuoliin liittyvät alakategoriat: matkustaja ja läheinen, matkakorvausjärjestelmä, kuljettaja sekä ympäristö. Nämä vastaavat myös konversiotekijöitä: henkilökohtaiset, yhteiskunnalliset ja ympäristöön liittyvät tekijät. Samalla yleisempinä teemoina, yläkategorioina alkoivat hahmottua henkilökohtaisten tarpeiden mukainen tuki ("Huolenpito ihmisestä”) sekä mekanistisempi järjestelmän toiminta ("Mekaaninen matkakorvausjärjestelmä”). Koodit asettuivat yläkategorioiden alle siten, että molempien yläkategorioiden alla on sekä auttavia että estäviä tekijöitä (ks. Taulukko 1). Esimerkiksi kommunikointi oli este huolenpidon yläkategoriassa, mutta kommunikointi ja matkustajan tunteminen olivat siinä myös apuna. Koodeja oli yhteensä 44 ja alakategorioita 7 .

Taulukko 1. Matkojen toteutumista estävät ja auttavat tekijät, kategoriat ja esimerkkejä koodeista

\begin{tabular}{|c|c|c|}
\hline Koodi & Alakategoria & Yläkategoria \\
\hline APU_Esteettömyys & Matkakorvausjärjestelmä & \multirow{4}{*}{$\begin{array}{l}\text { Mekaaninen matkakorvaus- } \\
\text { järjestelmä }\end{array}$} \\
\hline ESTE_Osaaminen & Kuljettaja & \\
\hline ESTE_Voinnin muutos & Matkustaja ja läheinen & \\
\hline ESTE_Sää & Ympäristö & \\
\hline APU_Hoitojen yhdistely & Matkakorvausjärjestelmä & \multirow[t]{3}{*}{ Huolenpito ihmisestä } \\
\hline ESTE_Kommunikointi & Kuljettaja & \\
\hline APU_Ennakointi & Matkustaja ja läheinen & \\
\hline
\end{tabular}




\section{Tulokset}

Mekaaninen toiminta ei ota huomioon erityisyyttä

Tulokset on jaoteltu kahden analyysista nostetun yleisemmän teeman, mekaanisen matkakorvausjärjestelmän ja ihmisen huolenpidon, mukaan. Teemat kuvastavat koettuja liikkumiseen liittyviä toimintavalmiuksia lisääviä ja rajoittavia puolia.

Matkustajilla, niin hoivaa tarvitsevilla kuin heidän läheisilläänkin, on erilaiset lähtökohdat liikkumiseen. Toimintavalmiuksia rajoittivat henkilökohtaiset fyysiset ja psyykkiset tekijät. Läheisen fyysinen kunto, esimerkiksi se, miten hän jaksoi työntää pyörätuolia tai nostaa matkustajaa, vaikutti usein matkanteon vaihtoehtoihin. Matkustajilla auton ajaminen tai ulkona itsenäisesti liikkuminen oli mahdotonta heikon näön vuoksi tai julkisten liikennevälineiden käyttö ei onnistunut psyykkisen sairauden takia. Fyysiset tekijät saattoivat vaikuttaa matkaan myös kiireellisenä lähtönä matkustajan nopeasti muuttuneen voinnin vuoksi. Joidenkin matkustajien vointi saattoi muuttua matkan aikana, matkustaja voi esimerkiksi pyörtyä. Tämä vaatii matkustajan tuntemusta, huolellisuutta ja ajan varaamista pysähtymiseen.

Esteettömyyteen liittyvät tekijät eivät aina vastanneet tarpeisiin. Portaat, ovensuut, valot, auton istuimen korkeus, tuoksut ja turvavyöt saattoivat helpottaa tai vaikeuttaa autoon sisään ja siitä ulos liikkumista ja matkantekoa. Omaistaan hoitavilla oli omaa kokemusta siitä, että kuljettajan tulisi auttaa matkustaja matkan ajaksi tiettyyn asentoon hoidon tai vamman vuoksi. Esteetön matkanteko ei ollut saatavilla automaattisesti tai kaikkialla. Etenkin invataksien saamisessa oli koettu haasteita ja joskus varattuja aikoja oli jouduttu perumaan tämän vuoksi. Tietyllä yrityksellä saattoi olla enemmän sopivia autoja kuin toisella.

Esteettömyys auttoi muuntamaan resursseja toimintavalmiuksiksi ja mahdollisti matkustajien omaa liikkumista. Lapsi pystyi olemaan paremmin pyörätuolissa taksissa kuin omassa autossa, ja itse matkustava uskalsi lähteä liikkeelle rollaattorin kanssa.

Taksimatkojen onnistumiseen vaikuttivat taksin tilaamisen onnistuminen ja taksin saapuminen. Matkan tilaaminen tilausvälityskeskuksesta edellytti keskukseen soittamista. Keskitetyn järjestelmän sanottiin hankaloittaneen tilaamista, sillä matkustajalla kului enemmän aikaa, soittamisesta tuli kuluja, kuljettajaa ei saanut valita ja määränpää oli joskus merkitty väärin. Soittaessa oli saatu jonottaa, puhelu katkesi kahden minuutin jälkeen ja soittaminen oli työlästä, vaikka toisinaan pääsi kohtuullisen hyvin läpi. Joskus kuljettajilla oli kiirettä, eikä kyytiä otettu. Järjestelmä kulutti matkustajan resursseja.

Joskus se tulee ihan pian, joskus ei, kun on kiirettä, niin kukaan ei ota sitä. Jos niil on muиta ajoa ja pidempää ajoo, niin ei ne ota näit pikkukeikkoja. Siellä istumme sitten ihmettelemässä.Ja näit inva-autoja on [kaupungissa] hyvin vähän.

(omainen 7)

Tilaamisen tapa liittyi siihen, miten sujuvaksi järjestelmä koettiin. Tilaamista helpotti kyytien tilaaminen nippuna 
esimerkiksi kuukaudelle tai tulevista kyydeistä sopiminen matkan aikana, mikä vähensi tilaamiseen kuluvaa aikaa. Eräs itse matkustava pohti, miksei koko vuoden matkoja voisi tilata kerralla. Eräs omaistaan hoitava ei uskaltanut sekaannuksia peläten tilata säännöllisiä käyntejä pidemmäksi aikaa.

Myös tässä tutkimuksessa matkan onnistumista vaikeutti se, että taksi ei saapunut sovittuun aikaan (esim. Kiljunen 2012 ja Sirola \& Nurmi-Koikkalainen 2014). Pelko myöhästymisestä aiheutti huolta. Taksin saapuminen oli usein epävarmaa: taksi oli jäänyt saapumatta tai tullut myöhässä, tai tilausaika oli merkitty väärin. Silloin kun taksia ei kuulunut, oli keskukseen soitettu itse uudelleen - taksit eivät olleet matkustajaan yhteydessä. Kun sairaus hoitoineen vei voimat, oli kuljetuksen järjestäminen ja odottaminen tämän jälkeen mahdotonta. Kyytejä yhdisteltäessä usean matkustajan tilanne saattoi vaikuttaa matkaan. Yhdistely sopi matkustajille, jos oltiin ajoissa perillä. Hyviäkin kokemuksia oli: yksi haastateltava ei ollut joutunut odottamaan kyytiä ja toisen mielestä järjestelmä oli toiminut itsellä pääpiirteissään hyvin.

Joskus on - - tullu ihan suht silleen - muntamissa minuuteissa mut kyl se - pääsäntösesti on sitä että - - on saanu odottaa ja - - tietysti näkkyy riippuvan siitäki, että millanen - - on säätilanne.

$--$

- - Ja- - autoista, minkä verran niitä on saatavilla.

(matkustaja 4)

Se on tympiä olla, ku autoa oottaa ja tunnin myöhässä. [naurahtaa] Pitkä matka.

(omainen 4)
Taksimatkat piti tilata tilausvälityskeskuksesta, jolloin kuljettajaa ei voinut valita itse, ellei matkustajalla ollut vakiotaksioikeutta. Tutun kuljettajan koettiin helpottavan matkustusoikeuden hyödyntämistä, sillä tämä oli koettu muun muassa täsmälliseksi ja aktiiviseksi ja tämä tunsi matkustajan. Mahdollisuudet tähän olivat muuttumassa tilausvälityskeskusten käyttöönoton vuoksi. Muutamalla haastateltavista muutos oli juuri tulossa tai tullut ja siitä oltiin huolestuneita. Toisilla oli tästä jo kokemusta ja toive tutusta kuljettajasta riippui tarpeista. Vakiotaksioikeuden saamista pidettiin liian tiukkana: hoivan tarvitsijan olisi esimerkiksi pitänyt olla kuntoutuksessa tietyn ikäisenä, tai itse matkustavan tilanteesta ei ollut kattavaa kuvaa. Raskaimpia matkoja tekeville toivottiin helpotusta. Asiaan haluttiin vaikuttaa (itse matkustava), mutta kun oikeuden edellytykset eivät olleet tiedossa, tämä oli vaikeaa.

$$
\begin{aligned}
& \text { Et - - se tekee tän - hulluks - -, no } \\
& \text { nyt mä pääsen - et saadaan kun ei oo } \\
& \text { olemassakaan semmosta, joka - - kasais } \\
& \text { kokoon-- nää kaikki - lääkärinlausun- } \\
& \text { not mitä on joka puolelta. Ei kukaan kato } \\
& \text { yleiskuvaa ja yleiskuntoo. } \\
& \text { (matkustaja 6) }
\end{aligned}
$$

Kuljetuksia oli käytettävä tiettyyn tarkoitukseen. Kunnan matkat on tarkoitettu asiointiin ja vapaa-ajan matkoihin, eikä kunta korvaa matkoja, jos niitä saa muun lain, kuten sairausvakuutuslain perusteella. Joillakin matkustajilla oli kokemusta erilaisista järjestelmistä, ja järjestelmien sääntöjen koettiin rajoittavan liikkumisen vaihtoehtoja: kysyttiin, miksi kunnan matkoja piti käyttää vain virkistykseen, kun oli tarve päästä 
lääkäriin.Toisaalta nähtiin mielekkäämpänä hoitaa yhdellä kertaa useita asioita.

Matkoihin ja niiden järjestämiseen käytettävä aika ja raha ovat resursseja, jotka voisi käyttää toisinkin, jolloin niiden käytöstä määrääminen rajoitti valmiuksia tehdä muita asioita. Matkojen yhdistämiseen tuhlautuvaa aikaa kommentoitiin enemmän kuin perille ehtimistä näillä matkoilla. Yhdistelyä piti esimerkiksi odottaa puoli tuntia, yhteiskuljetukset kestivät pidempään kuin matkat yksin, matkustajien ajalla ei koettu nähtävän merkitystä ja työssä käyvällä olisi muutakin tekemistä kuin hoidossa käyminen. Ajankäyttöä helpotti kuljettajan ennakointi, esimerkiksi matkustajan vapautumisen tiedustelu osastolta.

Ympäristön olosuhteet vaikuttivat perille ehtimiseen ja matkantekoon, kun tietöihin ja sähähn piti varata aikaa. Sääolot vaativat ajamiseen liittyvää osaamista. Taksimatkan onnistuminen riippui myös paikkakunnan taksien määrästä. Joillakin paikkakunnilla oli vain yksittäisiä kuljettajia.

\section{Huolenpito ihmisestä vahvistaa luottamusta}

Huolenpito vaikutti matkustajien toimintavalmiuksiin esteettömyyden tavoin. Yksityiskohdat olivat merkityksellisiä. Matkan toteutumisessa oli auttanut, että kuljettajat huolehtivat turvallisesti autoon, saattoivat sisälle, auttoivat ovissa, hakivat sisältä, ajoivat myös paluumatkan, tukivat liikkumisessa ja auttoivat jos oli jotakin mitä tarvitsi. Kuljettajat olivat tuoneet monia matkustajia sisälle hoitopaikkaan ja hakeneet sieltä, mutta kaikki eivät. Huolehtiminen oli tarpeen myös sen vuoksi, että matkustaja saattoi olla hoidon jälkeen voimaton, pyörtyä tai tarvita pyörätuolia. Avun saamisen kannalta oli tärkeää, että välityskeskus informoi tarpeista kuljettajaa tai että kuljettajat informoivat toisiaan, jos kuljettaja vaihtui. Kun apu oli oikeanlaista ja riittävää, mahdollisuudet liikkua oman päätöksen pohjalta vahvistuivat.

Et ku muutaman kerran kävi tässä sillee, että oli vieraita taksi, ja ne jätti [matkustajan] pihamaalle, ja siinäpä sitä oltiinki sitte. Hän kaatui sinne, ja se oli aivan kauheeta. Et mää pelkään, että tämmöstä ei vaan tulis. (omainen 8)

Avun saamiseen liittyi kuljettajien kommunikointi matkustajien kanssa: miten kuljettaja huomioi matkustajan ja selvitti aktiivisesti tämän tarpeita. Kommunikoinnin koettiin olleen vaihtelevaa eri kuljettajien välillä. Eräs kuljettaja ei ollut neuvonut näkövammaista matkustajaa kadulla olleista esteistä. Joskus kuljettaja ei uskaltanut kysellä oikeaa matkustajaa etsiessään tätä aulatiloista.

Yhtäältä kuljetus on väline sairaanhoitoon tai kuntoutukseen pääsemiseksi. Keskiössä ei välttämättä ole matkan kohtuullisuus matkustajan kannalta. Palvelu liittyy matkan miellyttävyyteen, mutta joskus se saattoi olla edellytys matkan toteutumiselle ylipäänsä. Useat haastateltavat kokivat, että palvelun laatu oli vaihdellut kuljettajasta riippuen. Tämä ei ollut aina oma-aloitteinen, vaan oli joskus esimerkiksi istunut autossa odottamassa matkustajaa. Matkan päämäärän varmistamista pidettiin tarpeellisena. Ajotapa vaikutti esimerkiksi niin, että jotkut kuljettajat olivat ajaneet kuoppaisia teitä kovaa vauhtia, vaikka 
tästä olisi aiheutunut kipua. Toisaalta matkustaminen oli myös sosiaalista, kuten aiemmissa tutkimuksissa (Sipponen 2006; Tedre ja Pulkkinen 2011) on havaittu, eikä kommunikaatio ollut siksi yhdentekevää matkan miellyttävyyden kannalta.

Kun matkustaja luotti kuljettajaan, hän uskalsi lähteä liikkeelle. Luottamus vahvisti näin liikkumiseen liittyviä toimintavalmiuksia. Kuljettajien aktiivinen kommunikointi vahvisti luottamusta. Kerrottiin esimerkiksi, että tuttu kuljettaja oli järjestänyt toisen kuljettajan ja informoinut tätä avustamistarpeista, jos ei itse päässyt. Tuttu kuljettaja oli ilmoittanut myöhästymisestä ja tiedustellut osastolta, milloin matkustaja pääsi hoidosta. Kokeneita ja päteviä kuljettajia arvostettiin.

Luottamuksen ansiosta kuljettajat saattoivat hoitaa matkan kokonaisuudessaan. Kun kuljettaja tunsi matkustajan tarpeet, saattoi omainen lähettää hänet lyhyelle matkalle ilman saattajaa (vrt. myös Puumalainen ym. 2014), eikä tarvinnut selittää miksi toimittiin tietyllä tavalla. Kuljettaja tiesi hoidon jälkeisen avuntarpeen, osasi auttaa sairaskohtauksessa ja käyttää avustamiseen sopivia otteita.

jos mä otan pystymettäst siihen jonkun,-ja [matkustaja] saa kohtauksen, niin sit se on kyl ihan liemessä- - sen kanssa. (omainen 7)

Luottamus lisäsi varmuutta perille pääsystä. Uuden järjestelmän ja siihen liittyvien muutosten kynnyksellä omaista hoitavaa pelotti, huolehtivatko kuljettajat huonokuntoisesta matkustajasta. Hän oli aiemmin voinut luottaa kyyteihin, mikä oli ollut tärkeää, kun elettiin sairauden ehdoilla. Tällöin tuttuus kompensoi epävarmuutta ja muiden voimavarojen niukkuutta. Saman yrityksen ja tutun kuljettajan koettiin tuovan turvaa. Luotettavuus nousi esille myös aiemmissa tutkimuksissa ja matkoja oli jätetty käyttämättä luottamuspulan vuoksi (esim. Mölkänen 2008; Asikainen 2015; Salminen 2015).

Tunteminen oli myös psykologinen tekijä: vanhojen ihmisten sanottiin olevan tottuneita tuttuihin kuljettajiin, tuttuus lisäsi luottamusta kyydin tulemiseen, tuttua kuljettajaa pidettiin mielekkäämpänä esimerkiksi autistiselle tai aivovamman saaneelle matkustajalle, toisaalta maalla toiset ihmiset tunnettiin ja tiedettiin mihin kukin halusi mennä. Kuljettajien läsnäolo oli osalle matkustajista merkityksellistä.

Matkustaminen verotti jaksamista, mikä vaikutti liikkumiseen liittyviin valmiuksiin ja mahdollisuuksiin tehdä muita asioita. Matkustajien jaksaminen nousi esille useasti, joskus myös omaisten. Matkustamisen tarvetta ja vaivaa vähensivät (itse matkustavan) terveydenhuollon eri käyntien yhdistäminen samalle päivälle ja (omaistaan hoitavalla) hoidon järjestäminen kotipaikkakunnalla. Jälkimmäisessä tapauksessa potilaiden hoitoja järjesteltiin samalle päivälle, jolloin erikoislääkärit kävivät kotipaikkakunnalla. Tämä vapautti aikaa ja voimia muuhun.

Matkustajien jaksamisen vuoksi toivottiin, että kuljettajat katsoisivat matkustajien kuntoa. Joskus esimerkiksi noudatettiin tiukasti tietokoneelta saatua reittiä ja vietiin ensin toinen matkustaja perille, vaikka ajettiin matkustajan ko- 
din ohi. Kyytien yhdistely vaikutti jaksamiseen matkan pidentymisen vuoksi. Yhdellä matkalla saattoi mennä koko päivä. Kuljettaja helpotti läheisten jaksamista, kun heidän ei tarvinnut lähteä matkalle mukaan tai kun kuljettaja auttoi raskaissa tehtävissä, kuten pyörätuolin työntämisessä. Tämä säästi läheisen "fysiikkaa", vapautti heidän aikaa ja voimia ja vaikutti siten mahdollisuuksiin valita mitä tekee.

- - jos se sama kuski jakaa eri puolille tonne vaikka sanotaan [kaupungin pohjoisosaan], niin [yskähtää - - se voi olla, että mää oonki siinä sitte viimesenä ja pä̈sen pois, ni se voi olla tunti lisää, jopa enemmän. (matkustaja 5)

Mahdollisuus liikkua omalla autolla lisäsi liikkumisen vaihtoehtoja ja valmiuksia tehdä erilaisia asioita. Omalla autolla kulkiessa saattoi hoitaa useamman asian kerralla, mikä toi joustavuutta omaan elämään. Esimerkiksi eräs omaistaan hoitava kävi terapian aikana kaupassa. Matkojen rajattu käyttötarkoitus kapeutti vapautta valita. Myös perille ehtimistä saatettiin varmistella ajamalla autoa itse. Tällöin pääsi varmasti lähtemään silloin, kun tarvitsi.

\section{Pohdinta}

Tutkimuksessa kysyttiin, miten asiakkaat kokevat sairausvakuutuksen matkakorvausjärjestelmän lisäävän tai rajoittavan liikkumiseen liittyviä toimintavalmiuksia. Niitä rajoittivat matkakorvausjärjestelmän mekaanisuus ja vahvistivat henkilökohtainen huolenpito. Matkan onnistuminen ja resurssien muuntaminen toimintavalmiuksiksi ja edelleen saavutetuiksi toiminnoiksi johtui useista henkilöiden tilanteisiin liittyvistä konversiotekijöistä. Perille pääsyyn vaikuttivat matkustajan henkilökohtaiset fyysiset ja psyykkiset ehdot, kuten liikkumisen esteet ja voinnin muutokset, läheiseltä saatava apu sekä ympäristöön liittyvät tekijät, kuten sää. Palveluun pääsyyn vaikuttavia yhteiskunnallisia tekijöitä olivat muun muassa taksin tilaamiseen ja saapumiseen liittyvät seikat sekä kuljettajan osaaminen ja matkustajasta huolehtiminen. Taksien koettu epätäsmällisyys aiheutti matkustajille huolta ja verotti heidän aikaansa.

Matkustajien kokemusten perusteella toimintavalmiuksien realisoituminen edellyttäisi riittävää tukea, vähäisempää aikaa muille itselle tärkeille asioille ja epävarmuuden sietämistä. Järjestelmän kehittäminen edellyttäisi ainakin täsmällisyyttä aikatauluissa, matkustajan tarpeiden tuntemista sekä kuljettajien osaamista ja aktiivisuutta. Se mitä järjestelmän näkökulmasta katsottiin kustannustehokkaaksi toimintatavaksi, matkustajan näkökulmasta vaikutti konversiotekijöiden kautta tämän voimavaroihin.

Tiettyjen erityisryhmien toimijuus näyttäisi mahdollistuvan tutun kuljettajan avun kautta. Matkustajalle oikeanlaisen ja riittävän avun saaminen saattoi olla lähtökohta sille, että pystyi ylipäänsä tekemään jotakin mielekästä tai tärkeää (Tedre 2000). Toimijuus muotoutuu eletyissä sosiaalisissa suhteissa (McNay 2004) ja on riippuvaista toisista ihmisistä, kuten kuljettajan huolehtimisesta. Sosiaaliset suhteet välittävät rakenteita ja ilmentävät palveluille asetettuja edellytyksiä. Keskeisiä suhteita ovat matkustajan, hänen läheistensä, kuljettajan 
ja terveyspalvelujen tarjoajien suhteet, joihin liittyvät kullekin taholle palvelujen määrittämät roolit. Matkustajalta vaadittiin tilaamiseen ja taksin saapumiseen liittyvän epävarmuuden sietämistä. Toiveena oli, että matkojen sujumiseen hyvin voisi luottaa. Luottamus merkitsi varmuutta matkan onnistumisesta ja matkustajan pärjäämisestä.

Konversiotekijät saavat matkakorvausjärjestelmän näyttäytymään matkustajan silmissä saavutettavana. Ne vaikuttavat siten kokemukseen osallisuudesta ja mahdollisuudesta käyttää palveluja. Palvelun saavutettavuudella on merkitystä sen kannalta, kokevatko ihmiset, että palveluja kannattaa käyttää.

Haastateltavat osoittivat tyytymättömyyttä matkojen tekemiseen liittynyttä runsasta ajankäyttöä kohtaan. Matkakorvausjärjestelmä vaikuttikin liikkumiseen liittyvien toimintavalmiuksien ohella muihinkin toimintavalmiuksiin. Hyvinvoinnin arvioimiseksi on arvioitava ihmisen erilaisia toimintoja (Sen 1993). Jos hyvinvoinnin tavoittelu heikentää toisen tärkeän toiminnon, kuten työnteon tai mielekkään elämän, saavuttamista - taksimatkat vievät esimerkiksi merkittävän osan päivästä - hyvinvointi voi jopa heikentyä. On huomionarvoista, että elämä sairauden kanssa saattaa olla jo ennestään melko sidottua. Huttusen (2019) opinnäytteessä kuljetuspalvelun siirtyminen keskitettyyn tilauspalveluun sai matkustajat sopeuttamaan elämäänsä järjestelmän toimintatapoihin, esimerkiksi vähentämään sosiaalista elämäänsä. Tällöin liikkumisen vapaus ja seniläisittäin vapaus elää oman näköistä elämää kapenevat.
Sairausvakuutuksen matkakorvausjärjestelmän kustannuksia on pyritty rajoittamaan yhdistelemällä matkoja ja korottamalla omavastuuosuutta. Kuljetusten avaaminen kaikille järjestelmään liittyneille kuljettajille sisältää uusliberalistisen idean markkinoiden vapauden lisäämisestä, mutta vain yhdelle taholle. Yksilön vapaus valita kuljettaja kapenee, koska asiakkaat eivät voi itse valita kuljettajaa, vaan sen tekee Kela. Samalla tuttuudesta syntyvää yhteisöllisyyttä heikennetään. Valinnanvapaudella voidaan tukea yksilöllisiä tarpeita vastaavien palvelujen järjestämistä, jos asiakkaat voivat itse valita mieleisensä vaihtoehdon.

Matkakorvausjärjestelmä näytti toimintavalmiuksien rajoittamisen kautta tuottavan jossakin määrin riippuvaista toimijuutta, kun avun saaminen vaatii "yhteiskunnallisten aikataulujen ja toimintamallien noudattamista" arjessa (Tedre 2000). Samalla matkustajan tai läheisen oma toimijuus vaikutti positiivisesti palvelujen saavuttamiseen ja lisäsi joustavuutta. Hyvät toimintavalmiudet parantavat toimintavalmiuksia edelleen. Myös YK:n vammaissopimuksessa (27/2016) edellytetään vammaisten henkilöiden henkilökohtaisen liikkumisen helpottamista "sillä tavalla kuin ja silloin kun he haluavat sekä kohtuulliseen hintaan”. Tämän perusteella kuljetuspalveluja voitaisiin kehittää joustavamman liikkumisen suuntaan, mikä tukisi myös sopimuksen ideaa täysimääräisestä osallisuudesta yhteiskuntaan.

On tärkeää huomata, että tehtäessä yksi järjestelmä kaikille, erilaiset tarpeet voivat jäädä tunnustamatta, vaikka matkustaja ja tilanne ovat usein erityisiä. 
Huomaamatta voivat jäädä tekijät, jotka mahdollistavat matkojen toteutumisen käytännössä. Olisi hyödyllistä huomioida matkustajien yksilölliset tarpeet myös siksi, että matkat olisivat kohtuullisia itsessään, etenkin kun niitä paljon käyttävillä ryhmillä on usein ennestään erityisiä terveyteen liittyviä tarpeita.

Toimintavalmiuksien lähestymistapa auttaa tarkastelemaan, miten resursseja voidaan hyödyntää erilaisissa tilanteissa ja millaisia vaikutuksia tällä on elämään laajemmin (Sen 2009). Tässä tutkimuksessa se auttoi ymmärtämään palvelun käyttöä mahdollistavia ja hankaloittavia tekijöitä. Lähestymistavan etuna on katseen tarkentaminen yksilön ja rakenteiden välisiin suhteisiin ja tosiasiallisiin toimintamahdollisuuksiin.

Tulosten tulkinnassa on pidettävä mielessä, että potilasyhdistysten kautta löydetyt haastateltavat olivat luultavasti keskimääräistä kiinnostuneempia palvelujen kehittämisestä ja mahdollisesti suhteellisen hyvin pärjääviä. On mahdollista, että matkoihinsa tyytyväiset eivät ole osallistuneet tutkimukseen. Toisaalta sairaus saattoi estää vastaajia osallistumasta. Aineisto painottui iäkkäisiin henkilöihin ja sen ulkopuolelle jäi erilaisia sairauksia koskevia kysymyksiä ja ensimmäistä kertaa matkustavien kokemuksia. Haastattelut antavat silti monipuolisen kuvan matkoja koskevista tarpeista ja niihin vastaamisesta, sillä tutkimukseen osallistui erilaisia tarpeita omaavia henkilöitä maantieteellisesti erilaisilta paikkakunnilta. Tutkimuksen perusteella ei voi kuitenkaan tehdä päätelmiä sairausvakuutuksen korvaamien matkojen toimivuudesta kokonaisuutena. Haastateltavien joukko oli pieni. Haastattelut tehtiin mat- kakorvausjärjestelmän yhden muutoskohdan ympärillä, jolloin tämä muutos oli erityisesti keskiössä. Muutos kuitenkin toteutui eri paikoissa eri aikaan. Kokemuksia matkojen yhdistelystä oli tässä aineistossa jonkin verran.

Matkakorvausjärjestelmää on kehitetty tämän tutkimuksen tekemisen jälkeen. Kela on kilpailuttanut palveluntuottajat ja heinäkuun 2018 alusta palveluntuottajalle alettiin maksaa matkakohtaista maksukertapalkkiota, joka on kaksinkertainen yhdistellyistä matkoista ja matkoja kannustetaan näin yhdistelemään. Muun muassa asiakkaan tilauspuhelumaksusta luovuttiin ja matkan on voinut tilata internetistä vuodesta 2019 alkaen, jos on pitkäaikainen todistus oikeudesta taksin käyttöön. Palveluntuottajilta vaadittuja palvelun edellytyksiä, kuten palvelun laatua sekä välittäjien ja kuljettajien tehtäviä, kuvataan palvelunkuvauksessa aiempaa tarkemmin. Moninaisiin tarpeisiin vastaamista on nähty tarpeelliseksi täsmentää. (Kela 2018d.)

Heinäkuun 2018 alusta voimaan tullut taksilain muutos avasi taksiliikenteen kilpailulle (L 320/2017). Taksien asemapaikkasääntely poistui, eikä lupien määrää enää rajoiteta. Alkuun Kelan korvaamilla taksimatkoilla havaittiin puutteita muun muassa autojen saatavuudessa ja tilauspuhelujen jonotusajoissa (Kela 2018f). Jää nähtäväksi vaikuttaako tämä matkoihin pidemmällä aikavälillä.Toteutuessaan sosiaali- ja terveydenhuollon palvelurakenteen uudistuksella lienee vaikutusta palvelujen sijaintiin ja näin matkoihin hoitopaikkaan. Matkapalvelujen järjestämiseen voi vaikuttaa myös se, että palvelujen ja matkojen rahoittaja olisi sama taho. 


\section{RAHOITUS}

Tutkimusaineisto kerättiin Kelan KKRLrahoituksella osittain toteutetussa, Helsingin yliopiston Sosiaalitieteiden laitoksen ja Kelan tutkimusryhmän yhteistyönä toteuttaman Sairausvakuutuksen matkakorvaukset -hankekokonaisuuden osatutkimuksessa Sairausvakuutuksen matkakorvausten merkitys arjessa. Kiitämme erikoistutkija Päivi Tillmania (Kela), joka vastasi hankekokonaisuudesta. Käsikirjoituksen työstämistä tuki myös Koneen Säätiö.

\section{ViITTEET}

1 Vakiotaksin käyttöön oli oikeus aiemmin Kelan lääkinnällisen kuntoutuksen vaikeavammaisilla asiakkailla, vaikeavammaisilla entisillä asiakkailla sekä asiakkailla, jotka täyttäisivät kriteerit, mutta joilla oli oikeus kuntoutukseen toisen lainsäädännön perusteella. Määritelmät viittasivat kuntoutuksen saamisen edellytyksiin laissa. Vuoden 2016 alusta lähtien kuntoutuksen myöntäminen ei ole enää ollut sidoksissa vammaisetuuksien saamiseen (L566/2005).Vaikeavammaisten lääkinnällinen kuntoutus muuttui myös vaativaksi lääkinnälliseksi kuntoutukseksi. Kun aiemmin näitä taksimatkoja ei yhdistelty, lain muutoksen jälkeen matkoja voidaan yhdistellä. (L 145/2015.)

2 Sen jakaa ne esimerkiksi henkilökohtaisiin tekijöihin, ympäristön olosuhteisiin, yhteiskunnallisiin ehtoihin, yksilöiden suhteelliseen asemaan liittyviin tekijöihin ja perheen sisäisiin eroihin.

3 Hankkeessa on aiemmin julkaistu samaa aineistoa hyödyntävä raportti (Turunen \& Tillman 2017). Aineisto on analysoitu uudestaan tätä artikkelia varten.

4 Potilasyhdistyksiä pyydettiin välittämään kutsua tutkimukseen niiden jäsenille ja haastateltavat ilmoittivat niille kiinnostuksestaan osallistua tutkimukseen. Kiinnostuneille lähetettiin tutkimuksesta tiedote ja osallistumisesta sovittiin puhelimen tai sähköpostin välityksellä. Omaista tai huoltajaa haastateltiin silloin, kun matkakorvausten saaja ei itse pystynyt vastaamaan tai oli alaikäinen.

5 Matkakorvauksia oli käytetty eri tavoin satunnaisista matkoista säännöllisiin viikoittaisiin matkoihin ja puolesta vuodesta kymmeniin vuosiin. Matkojen pituus vaihteli 1-160 kilometrin välillä. Viidellä yhdensuuntaiset matkat olivat usein tai aina lyhyitä (10 km tai vähemmän), kolmella yleensä tätä vähän pidempiä ja seitsemällä kymmeniä kilometrejä.

6 Myös täytesanat, merkitykselliset tauot ja tunneilmaisut, haastattelijan myötäilyt, mahdolliset kolmannet osapuolet tai haastattelun häiriöt litteroitiin. Täytesanat, toistot, keskeneräiset tavut ja lauseet, epäselvät kohdat ja haastattelijan myötäilyt poistettiin artikkelista.

\section{KirjallisuUs}

Adams, William C. (2015) Conducting semi-structured interviews. Teoksessa Kathryn E. Newcomer, Harry P. Hatry \& Joseph S. Wholey (toim.) Handbook of practical program evaluation. New Jersey: Wiley, 492-505. https://doi. org/10.1002/9781119171386.ch19

Asikainen, Esa (2015) "Me olemme postipaketteja". Tutkimus Helsingin vammaiskuljetuksista vuosina 2002-2007. Dissertations in Education, Humanities, and Theology 64. Joensuu: Itä-Suomen yliopisto.

Beyazit, Eda (2011) Evaluating social justice in transport: Lessons to be learned from the capability approach. Transport Reviews 31 (1), 117-134. https://doi.or g/10.1080/01441647.2010.504900

Deneulin, Séverine \& McGregor, J. Allister (2010) The capability approach and the politics of a social conception of wellbeing. European Journal of Social Theory 13 (4), 501-519. https://doi. org/10.1177/1368431010382762

Douglas, Mary \& Ney, Steven (1998) Missing persons: A critique of the social sciences. Berkeley: University of California Press.

Gaskell, George (2003) Individual and group interviewing. Teoksessa Martin W. 
Bauer \& George Gaskell (toim.) Qualitative researching with text, image and sound. London: Sage, 38-56.

Huttunen, Petri (2019) Vakiotaksista keskitettyyn matkojenyhdistelyjärjestelmään. Pro gradu -tutkielma. Helsinki: Helsingin yliopisto.

Hvinden, Bjorn \& Halvorsen, Rune (2018) Mediating agency and structure in sociology: What role for conversion factors? Critical Sociology 44 (6), 865-881. https://doi. org/10.1177/0896920516684541

Kela (2013) Palvelun kuvaus. Tarjouspyyntö $12 / 2013$. Liite 1 . Diaarinumero: 26/43/2013. http://www.kela.fi/documents/10180/1978560/Kilpailutetun+ alueen+ palvelukuvaus. pdf/193692f4769f-4e9e-84ad-eb5b9c46cc7b. Luettu 25.1.2019.

Kela (2018a) Näin haet matkakorvausta ja yöpymisrahaa. https://www.kela.fi/matkakorvaus-nain-haet. Luettu 25.1.2019.

Kela (2018b) Todistus matkakorvausta varten, SV 67. https://www.kela.fi/yhteistyokumppanit-laakarit-ja-terveydenhuolto-matkakorvaukset-todistus-matkakorvausta-varten. Luettu 25.1.2019.

Kela (2018c) Vakiotaksi. https://www.kela. fi/vakiotaksiasiakkuus. Luettu 25.1.2019.

Kela (2018d) Kelan sairausvakuutuksesta korvattavat matkat ja palvelut. Palvelunkuvaus. 8.1.2018. https://www.kela.fi/ documents/10180/3017929/Tilausv\% C3\%A4lityskeskusten+ palvelunkuvaus + $\% 28$ pdf $\% 29 / 472 f 93 \mathrm{e} 0-41 \mathrm{a} 4-4 \mathrm{f5} 2-\mathrm{a} 9 \mathrm{df}-$ 760336f23d04. Luettu 22.2.2019.

Kela (2018e) Taksimatkat. https://www. kela.fi/taksimatkat. Luettu 25.1.2019.

Kela (2018f) Kelan hallitus edellyttää välityskeskuksilta ripeitä toimia Kelan korvaamien taksimatkojen puutteiden korjaamisessa. 31.8.2018. https://www. kela.fi/ajankohtaista-yhteistyokumppanit/-/asset_publisher/WQHcJ3JiaK7b/ content/kelan-hallitus-edellyttaa-valityskeskuksilta-ripeita-toimia-kelankorvaamien-taksimatkojen-puutteidenkorjaamisessa. Luettu 22.2.2019.

Kela (2019a) Matkakorvaukset. https:// www.kela.fi/matkat. Luettu 25.1.2019.

Kela (2019b) Kelan tilastotietokanta Kelasto. http://www.kela.fi/kelasto. Luettu 24.2.2019.
Kiljunen, Sarianna (2012) Kuopiolaisten kuljetuspalveluiden järjestäminen ja matkojenyhdistelykeskuksen toiminta. Asiakastyytyväisyystutkimus 2012. Kuopio: Kuopion kaupunki.

L 380/1987. Laki vammaisuuden perusteella järjestettävistä palveluista ja tukitoimista.

L 1224/2004. Sairausvakuutuslaki.

L 566/2005. Laki Kansaneläkelaitoksen kuntoutusetuuksista ja kuntoutusrahaetuuksista.

L 1256/2014. Laki sairausvakuutuslain muuttamisesta.

L 1301/2014. Sosiaalihuoltolaki.

L 145/2015. Laki Kansaneläkelaitoksen kuntoutusetuuksista ja kuntoutusrahaetuuksista annetun lain muuttamisesta.

L 320/2017. Laki liikenteen palveluista.

Lehtola, Ilkka \& Tedre, Silva (2014) Kulkeminen maaseutututkimuksessa. Janus 22 (3), 279-287.

McNay, Lois (2004) Agency and experience: gender as a lived relation. Teoksessa Lisa Adkins \& Beverley Skeggs (toim.) Feminism after Bourdieu. Oxford: Blackwell, 175-190. https://doi.org/10.1111/ j.1467-954X.2005.00530.x

Mölkänen, Jenni (2008) Helsingin matkapalvelukeskus. Selvitys matkapalvelun käyttämättömyyden syistä. Helsingin kaupungin sosiaalivirasto, selvityksiä 4 . Helsinki: Helsingin kaupunki.

Navarro, Vicente (2000) Development and quality of life: A critique of Amartya Sen's development as freedom. International Journal of Health Services 30 (4), 661674. https://doi.org/10.2190/10XKUYUC-E9P1-CLFX

Nordbakke, Susanne (2013) Capabilities for mobility among urban older women: barriers, strategies and options. Journal of Transport Geography 26, 166-174. https://doi.org/10.1016/j.jtrangeo.2012.10.003

Paltta, Päivi (2010) Sairausvakuutuksen korvaamat taksimatkat. Taksiyrittäjille tehdyn kyselytutkimuksen tuloksia. Nettityöpapereita 10. Helsinki: Kela.

Puumalainen, Jouni \& Laisola-Nuotio, Annika \& Ala-Kauhaluoma, Mika (2014) Toteutuuko liikkumisen vapaus? Kokemuksia ja näkemyksiä vammaisten henkilöiden liikkumisen mahdollisuuk- 
sista Suomessa. Invalidiliiton julkaisuja 27. Helsinki: Invalidiliitto.

Ryan, Jean (2019) Towards a capability approach to mobility: An analysis of disparities in mobility opportunities among older people. Lund: Lund University.

Salminen, Sirpa (2015) Kohtuulliset palvelut. Tapaustutkimus kuljetuspalvelujen uudelleen organisoinnista. Acta Universitatis Lapponiensis 311. Rovaniemi: Lapin yliopisto.

Sen, Amartya (1985) Well-being, agency and freedom: The Dewey Lectures 1984. The Journal of Philosophy 82 (4), 169221. https://doi.org/10.2307/2026184

Sen, Amartya (1993) Capability and well-being. Teoksessa Martha Nussbaum \& Amartya Sen (toim.) The quality of life. Oxford: Oxford University Press, 30-53. https://doi. org/10.1093/0198287976.003.0003

Sen, Amartya (2000) Development as Freedom. New York: Anchor Books.

Sen, Amartya (2009) The Idea of Justice. London: Allen Lane.

Sipponen, Tarja (2006) "Taksin katolla vilkkuu..." Kuljetuspalveluasiakas ja taksi. Ammatillinen lisensiaatintutkimus. Tampere: Tampereen yliopisto.

Sirola, Pia \& Nurmi-Koikkalainen, Päivi (2014) Kuljetuksesta liikkumiseen. Kuntakyselyn ja asiakashaastattelujen tuloksia vammaisten henkilöiden kuljetuspalveluista ja auton hankinnan tukimuodoista. Työpaperi 24. Helsinki: Terveyden ja hyvinvoinnin laitos.

Smith, Matthew Longshore \& Seward, Carolina (2009) The relational ontol- ogy of Amartya Sen's capability approach: Incorporating social and individual causes. Journal of Human Development 10 (2), 213-235. https:// doi.org/10.1080/19452820902940927

Svensk Kollektivtrafik (2017) ANBARO årsrapport 2016. Barometer för anropsstyrd trafik. Stockholm: Svensk Kollektivtrafik.

Tedre, Silva (2000) Hoivaa jokapäiväisten toistojen maailmassa. Yhteiskuntapolitiikka 65 (6), 520-526.

Tedre, Silva \& Pulkkinen, Anneli (2011) Kulkeminen avaimena ikääntyvien maalla asumisen mahdollisuuksiin.Yhteiskuntapolitiikka 76 (3), 300-308.

Tilastokeskus (2018) Väestö. Väestörakenne 31.12. https://www.tilastokeskus.fi/ tup/suoluk/suoluk_vaesto.html. Luettu 25.2.2019.

Tillman, Päivi \& Miettinen, Jani (2016) Kelan matkakorvausten kohdentuminen vammaispalvelulain ja sosiaalihuoltolain mukaisiin kuljetuksiin oikeutetuille. Rekisteritutkimus Oulusta vuodelta 2013. Työpapereita 102. Helsinki: Kela.

Tuomi, Jouni \& Sarajärvi, Anneli (2009) Laadullinen tutkimus ja sisällönanalyysi. Helsinki:Tammi.

Turunen, Elina \& Tillman, Päivi (2017) Kun vain lähdettäisiin ajoissa. Matkakorvausten käyttäjien kokemuksia sairausvakuutuksen korvaamista matkoista. Sosiaali- ja terveysturvan raportteja 6 . Helsinki: Kela.

Yleissopimus vammaisten henkilöiden oikeuksista 27/2016. 